\title{
Publisher Correction: FGF signalling controls the specification of hair placode-derived SOX9 positive progenitors to Merkel cells
}

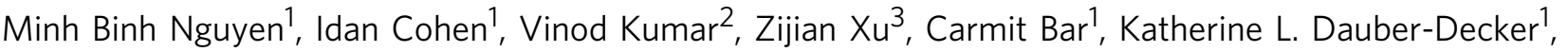 \\ Pai-Chi Tsai ${ }^{4}$, Pauline Marangoni ${ }^{5}$, Ophir D. Klein (10 ${ }^{5,6}$, Ya-Chieh Hsu ${ }^{4}$, Ting Chen ${ }^{3}$, Marja L. Mikkola ${ }^{2} \&$ \\ Elena Ezhkova (iD) ${ }^{1}$
}

Correction to: Nature Communications; https://doi.org/10.1038/s41467-018-04399-y, published online 13 June 2018.

The originally published version of this Article contained an error in Figure 2. In panel e, the blue bar was incorrectly labelled 'KRT8(+)/ TOMATO $(-)$ '. Furthermore, during the process of preparing a correction, the publication date of the Article was inadvertently changed to June $20^{\text {th }}$ 2018. Both of these errors have been corrected in the PDF and HTML versions of the Article.

Published online: 17 July 2018

\begin{abstract}
(c) (i) Open Access This article is licensed under a Creative Commons Attribution 4.0 International License, which permits use, sharing, adaptation, distribution and reproduction in any medium or format, as long as you give appropriate credit to the original author(s) and the source, provide a link to the Creative Commons license, and indicate if changes were made. The images or other third party material in this article are included in the article's Creative Commons license, unless indicated otherwise in a credit line to the material. If material is not included in the article's Creative Commons license and your intended use is not permitted by statutory regulation or exceeds the permitted use, you will need to obtain permission directly from the copyright holder. To view a copy of this license, visit http://creativecommons.org/licenses/by/4.0/.
\end{abstract}

(C) The Author(s) 2018

\footnotetext{
${ }^{1}$ Black Family Stem Cell Institute, Department of Cell, Developmental, and Regenerative Biology, Icahn School of Medicine at Mount Sinai, 1 Gustave L. Levy Place, New York, NY 10029, USA. ${ }^{2}$ Developmental Biology Program, Institute of Biotechnology, University of Helsinki, 00014 Helsinki, Finland. ${ }^{3}$ National Institute of Biological Sciences, 102206 Beijing, China. ${ }^{4}$ Department of Stem Cell and Regenerative Biology, Harvard Stem Cell Institute, Harvard University, Cambridge, MA 02138, USA. ${ }^{5}$ Department of Orofacial Sciences and Program in Craniofacial Biology, University of California San Francisco, San Francisco, CA 94143, USA. ${ }^{6}$ Department of Pediatrics and Institute for Human Genetics, University of California San Francisco, San Francisco, CA 94143, USA.

Correspondence and requests for materials should be addressed to E.E. (email: elena.ezhkova@mssm.edu)
} 